\title{
Ergenlerin Umutsuzluk ve Psikolojik Sağlamlıklarının Sahip Oldukları Değerler Açısından İncelenmesi ${ }^{1}$
}

\author{
Neriman Özge GÖKÇE ${ }^{2}$ ve Bülent DİLMAÇ3
}

\section{$\ddot{\mathrm{O} z}$}

Araştırmanın genel amacı ergenlerin umutsuzluk ve psikolojik sağlamlık düzeylerinin sahip oldukları değerler açısından incelenmesidir. Araştırmada genel tarama modelinin bir alt türü olan ilişkisel tarama modeli kullanılmıştır. Araştırmanın çalışma evreni 2013-2014 yılında Konya'da lise öğrenimini sürdüren ergenlerden oluşmaktadır. Çalışma grubu ise, bu ergenler arasından tesadüfî küme örnekleme yöntemi ile seçilmiştir. Araştırmada İnsani Değerler Ölçeği (IDÖ); Beck Umutsuzluk Ölçeği (BUÖ) ve California Yılmazlık Değerlendirme Ölçeği Lise Versiyonu (CYDÖ) kullanılmıştır. Araştırma "Yapısal Eşitlik Modeli" ne göre AMOS 19 Programı kullanılarak analiz edilmiştir. Araştırma bulguları sonucunda, ergenlerin sahip oldukları değerlerin arttıkça, psikolojik sağlamlık düzeylerinin de artış göstereceği; umutsuzluk düzeylerinin ise negatif yönlü olarak azalacağı ortaya çıkmıştır.

Anahtar Kelimeler: Değer, Psikolojik Sağlamlık, Umutsuzluk, Yılmazlık, Umut

\section{A Study of Adolescents' Hopelessness and Psychological Stability in Terms of 'Their Values}

\section{Abstract}

The aim of the study is to analyze adolescents' level of hopelessness and psychological stability in terms of their values. The relational screening model which is a sub-type of the general screening model was conducted in the study. Adolescents who studied in Konya in 2013-2014 took part the research and they were randomly selected. The Human Values Scale; Beck Hopelessness Scale (BHS) and the California Resilience Rating Scale High School Version (SCD) were conducted. The study was analyzed by using AMOS 19 Program via "Structural Equation Model". As a result it was found out that adolescent' values and psychological stability increase while level of hopelessness goes down.

Key Words: Value, Psychological Stability, Hopelessness, Resilience, Hope

\section{Atıf İçin / Please Cite As:}

Gökçe, N. Ö. ve Dilmaç, B. (2020). Ergenlerin umutsuzluk ve psikolojik sağlamlıklarının sahip oldukları değerler açısından incelenmesi. Manas Sosyal Araştırmalar Dergisi, 9(2), 752-763.

Geliş Tarihi / Received Date: 24.04.2019

Kabul Tarihi / Accepted Date: 05.11.2019

\footnotetext{
${ }^{1}$ Bu çalışma Özge Gökçek’in “Ergenlerin Umutsuzluk ve Psikolojik Sağlamlıklarının Sahip Oldukları Değerler Açısından İncelenmesi" Yüksek Lisans Tezinden üretilmiştir.

${ }^{2}$ Konya Milli Eğitim Müdürlügü, neriman.ozge@gmail.com

ORCID: 0000-0003-0869-7255

3 Prof. Dr. - Necmettin Erbakan Üniversitesi Ahmet Keleşoğlu Eğitim Fakültesi, bulentdilmac@gmail.com ORCID: 0000-0001-5753-9355
} 


\section{Giriş}

Değerler kavramı teorik yönden olduğu kadar, gelişen evren içinde yer edinmek isteyen insanoğlunu yakından alakadar etmesi açısından önem arz etmektedir. Hem toplumsal hem de ekonomik alanı ilgilendiren değişimlerin nihai neticesi (ve bazı zaman da vasıtası) olarak beliren yeni sosyal organizasyonların sıhhatli çalışması, kişilerde var olan değerlerin bu şekilde tanzimlerle uyum içinde bulunmasıyla yakından ilgilidir. Bu uyum problemi, toplumun sağlıklı analiz edilmesini, binaenaleyh değerlerin kapsamlı biçimde ele alınmasını gerektirmektedir.

Latin kökünden gelen değer sözcüğü "kıymetli olma" ve "kuvvetli olma" manalarına gelen "valere" kelimesinden gelmiş, "çoğunlukla kabullenilen, gipta edilen, önemli görülen, el üstünde tutulan şey" veya "birey açısından ehemmiyet arz eden; birey için varlık gösteren" manalarına gelir (Aydın, 2003, s. 122; Yıldırım, 2004; Timüçin, 1994). Değer bir şeyin; kendiyle özdeş türden şeyler arasındaki konumu, genellikle inanç gösterilen, istenen, tavırlar için bir ölçü şeklinde kullanıma geçirilen vakalar veyahut zıt duruma karşllk bireysel veyahut toplumsal seçimlerin durumunu gösteren inançlar şeklinde ifade edilebilir (Oktay, 2007; Aydın 2003; Akbaba-Altun, 2003). Değer "bir nesnenin arzulanabilir veyahut arzulanamaz olması yönündeki inançlar bütünüdür" (Güngör, 1993). Bir başka tanımda değer; bir madde, iss, ide veyahut faaliyetin teşkilat içindeki ehemmiyetini tayin eden nitelikler toplamı ve niceliktir ve madde, iş, ide veyahut faaliyete değer biçmede kullanılır (Başaran, 1992 Akt: Dilmaç, Bozgeyikli ve Çıkılı, 2008, s. 70).

Değerin toplumsal ve tarihsel şekilleri kişileri farklı şekilde etkileyebilmektedir (Gökçe, 1994). Bu yönden ele alındığında değer ile birey arasındaki bağ tek yönlü değildir (Aydın, 2003, s. 123). Bu açıdan değeri bireylerin sahip olduğu ya da tekrardan kazandığı davranışlarla da açıklamak mümkündür. Değer kişinin fikir ve davranış yapılarında birer ölçü olarak ortaya çıkar ve toplumun ayrılmaz bir parçasını oluşturur(Durmuş, 1996, s. 17). Değer tavırlarımıza yön verir; hareketlerimizi, hükümlerimizi, durumluk amaçlarımızı daha üst amaçlara ileterek, bizim nasıl bir birey olmamız gerektiğini ve nasıl davranacağımızı bildirir.(Simon, Howe ve Kirschenbaum, 1978, s. 29). Bu açıdan bakıldığında bireylerin sahip oldukları değerlerin, onların hayata bakışında, olayları algılayış ve yorumlayış biçiminde, yaşantısında çok etkin bir rol oynadığı düşünülmektedir.

Umut, gelecekle ilgili duygu ve beklentilerin pozitif olduğunu ortaya koyan ve karşımıza çıkabilecek negatif olaylarla baș etme kuvveti kazandıran mefhumdur (Çelikel ve Erkorkmaz, 2008, s. 123). Sağladığı kuvvetle kişinin kendini gerçekleştirebileceğine, olumsuz durumların altından kalkabileceğine inanmasına yardımcı olur. Umutsuzluk ise geleceğe yönelik beklentinin azalmasını, olumsuz düşünce ve inanışları içine alan bir anlamdadır. (Üngüren ve Ehtiyar, 2009, s. 2098).

Toplumumuzda sosyoekonomik düzeyde var olan olumsuzluklar, eğitim öğretim alanındaki birtakım noksanlıklar ve gelecek kaygıları duygusal olarak gençlerimizi olumsuz etkilemekte ve onlarda yarınlarıyla ilgili umutsuzluk düşüncesine neden olmaktadır (Özmen, Dündar, Çetinkaya, Taşkın ve Özmen, 2008, s. $9)$.

Kişinin gelecek günlere yönelik fikirleri ne kadar pozitif ise kendisiyle ilgili düşünceleri, özgüveni, kararll1lğ1 da o derece olumlu olurken tam tersi kişi ne kadar umutsuz ise gelecek beklentisi, özgüveni, olumlu bakış açısı o derece azalacaktır. Literatüre bakıldığında umutsuzluğun bireyin hayata bakış açısını, sıhhatini ve herhangi bir iş ile uğraşırken ortaya koyduğu verimi doğrudan etkilediğini ortaya koymaktadır (Abela ve Seligman, 2000; Abramson, Metalsky ve Alloy, 1989; Vinas Poch, Villar, Caparros, Cornella, Perez, \& Juan, 2004; Chang, D'Zurilla ve Mayder, 1994; Akt: Şengül ve Güner, 2012, s. 1). Kişinin umutsuzluk seviyesi arttıkça problem çözme, yaratıcllk, başarı ve deneyimlerini hayata olumlu şekilde aktarma yeteneği olumsuz etkilenmektedir. Bireyin kendinde meydana gelen bu negatif oluşumlar hem kendini hem de toplumu etkileyerek bireyin geleceği için bir tehdit oluşturmaktadır.

Literatüre bakıldığında ergenlerde umutsuzluk düzeyinin araştırıldığı az sayıda çalışma vardır ve bu çalışmaların bulguları tutarsızlık göstermektedir.

Psikolojik sağlamlık, stresli durumlarla karşılaştığında bunu kabullenip başa çıkmak için etkili bir yol izlemeyi, stresle başa çıkma yeterliliğini ifade eder (Luthar ve Cichetti, 2000; Rutter, 1987 Akt: Gizir, 2007, s. 115). Psikolojik sağlamlığa sahip olarak tanımlanan bireyler; sıkıntı ve stres durumlarında karamsarlığa kapılmak yerine bu sıkıntılı durumu bir firsat olarak algilayarak kendini işine veren ve mücadele eden, paniğe kapılmak yerine olayları kontrol edebilen dolayısı ile sıkıntılı durumları bile lehine çevirebilen ve stres düzeylerini bu olumlu özellikleri sayesinde azaltabilen bireyler olarak tanımlanmaktadır (Şahin, 2014 
Akt: Hoşoğlu, Fırıncı Kodaz, Yılmaz Bingöl ve Vural Batık, 2018, s. 220). Psikolojik sağlamlık, bireyin karşılaştı̆̆ negatif durumlar karşısında sergilediği olumlu tutum ve stresle baş edebilme yetisi şeklinde tanımlanmıştır (Block ve Kremen, 1996 Akt: Hoşoğlu, Fırıncı Kodaz, Yılmaz Bingöl ve Vural Batık, 2018, s. 219). Bireyde psikolojik sağlamlı̆̆ı gözlemleyebilmek maksadıyla eş veya ebeveyn kaybı, eşinden ayrılma, rahatsızlık, fakirlik, deprem, sel gibi yaralayıcı yaşantılar yaşadığında kendinde var olan koruyucu etmenleri nasıl devreye soktuğuna bakılmalıdır.

Psikolojik sağlamlık tıpkı bir su birikintine bir damla su düştügünde birikintinin dalgalanıp durulması ve eski haline dönmesi gibidir. Psikolojik olarak sağlam bireyler, sıkıntı ve stres durumlarında karamsarlığa düşüp pes etmek yerine mücadele eden, stresini yönetebilen ve bu olumlu özelliği sayesinde sorunu çözerek kendini geliştirebilen kişilerdir. (Garmezy, 1991 Akt: Eminağaoğlu, 2006, s. 1). Masten ve Garmezy'e (1985) göre, psikolojik sağlamlık kişinin stresli yaşantının ardından eski davranış biçimine dönebilme yeteneğidir, küllerinden yeniden doğmak gibidir (Osterling ve Hines, 2006, s. 242).

Bu bağlamda bireyin sahip olduğu değerlerin hem psikolojik sağlamlığını hem de umutsuzluk düzeyini etkileyeceği düşünülmüştür.

\section{Yöntem}

Araştırmada ilişkisel tarama modeli kullanılmıştır. İlişkisel tarama, İki ya da daha fazla değişken arasındaki ilişkiyi belirlemek ve neden-sonuç ile ilgili ipuçları elde etmek amacıyla yapılmaktadır (Büyüköztürk vd., 2008). Araştırma kapsamında ergenlerin sahip oldukları değerler ile umutsuzluk ve psikolojik sağlamlık düzeyleri arasındaki yordayıcı ilişkiler ortaya koyulmaktadır.

\section{Evren - Örneklem}

Araştırmanın çalışma grubu, 2013-2014 Eğitim-Öğretim yllında Konya il merkezinde ve ilçelerinde bir meslek, iki Anadolu lisesi olacak şekilde üç değişik okulda ve değissik sınıf seviyelerinde eğitim almakta olan ergenlerin oluşturduğu çalışma evreni içinden uygun örnekleme metoduyla seçilmiştir. Çalışma grubunun, 338' si kız, 250’ si erkek öğrenciden meydana gelmektedir. Araştırmaya toplam 588 öğrenci katılmıştır.

\section{Veri Toplama Araçları}

Kişisel Bilgi Formu. Katılımcıların yaş, cinsiyet, eğitim durumu, anne ve baba eğitim durumlarını belirlemek amacıyla araştırmacı tarafından hazırlanan kişisel bilgi formu kullanılmıştır.

Veri Toplama Aracmm Adr. Makalenin veri toplama aracı/araçları ile ilgili bilgiler burada yer alacak. Makalelerde yazı karakteri olarak "Garamond" yazı karakteri kullanılmalıdır. Özel bir yazı tipi (font) kullanılması gerektiren makalelerde, kullanılan yazı tipi de yazıyla birlikte gönderilmelidir. Makale sayfa düzeninde üst, sağ ve sol kenarlardan $2,5 \mathrm{~cm}$, alttan $1,5 \mathrm{~cm}$ boşluk bırakılmalıdır. Makale metni "Garamond" yazı karakteri, 11 punto büyüklüğünde, tek satır aralığı, önce ve sonra 6 nk aralık bırakılarak" yazılmalıdır. Metin tek sütun olarak yazılmalıdır. Her bir paragraf en az üç cümleden oluşmalıdır. Paragraflar $0,75 \mathrm{~cm}$ 'lik girinti ile başlamalı, paragraf aralarında boşluk bırakılmamalıdır.

Insani Değerler Ölçeği (IDÖ). Bu araştırmada, öğrencilerin insani değerlerini belirlemek için, Dilmaç (2007), tarafından ortaöğrenim düzeyindeki öğrenciler (ergenler) için geliştirilen "İnsani Değerler Ölçeği (IDÖ)" kullanılmıştır. Ölçekte, insani değerler süreci a. Sorumluluk (7 madde) b. Dostluk/Arkadaşlık (7 madde) c. Barışç Olma (7 madde) d. Sayg1 (7 madde) e. Hoşgörü (7 madde) $\quad$ f. Dürüstlük (7 madde) olarak altı boyutta toplam 42 madde ile ölçülmektedir. Bu ölçek bireysel veya gruplar halinde uygulanabilen Likert tipi bir ölçektir. Ölçekteki maddeler beş "Likert Tipi" (A: Hiçbir Zaman, B: Nadiren, C: Ara sıra, D: Sık Sık, E: Her Zaman) bir dereceleme ölçeği seklinde ifade edilmiştir. Maddeler A:1- B:2- C:3- D:4- E:5 seklinde puanlanmıştır. Puanların artması/azalması kişilerin insani değerlere daha çok sahip olduğunu/olmadığını göstermektedir.

İÖ'nün güvenirlik çalışması için iç tutarllık katsayıları (Cronbach Alpha) hesaplanmıştır. 7 maddeden oluşan "Sorumluluk" alt ölçeğinin iç tutarlılık katsayısı alfa: .73 olarak hesaplanmıştır. 7 maddeden oluşan "Dostluk/Arkadaşlık" alt ölçeğinin iç tutarlılık katsayısı alfa: .69 olarak hesaplanmıştır. 7 maddeden oluşan "Barışçı Olma" alt ölçeğinin iç tutarllılı katsayısı alfa: .65 olarak hesaplanmıştır. 7 maddeden oluşan "Sayg1" alt ölçeğinin iç tutarlılık katsayısı alfa: .67 olarak hesaplanmıştır. 7 maddeden oluşan "Dürüstlük" alt ölçeğinin iç tutarlılık katsayısı alfa: .69 olarak hesaplanmıştır. 7 maddeden oluşan "Hoşgörü" alt ölçeğinin iç tutarlllık katsayısı alfa: .70 ve .42 maddelik tüm ölçek için iç tutarlılık katsayısı 
ise alfa .92 bulunmuştur. Bu kararllık katsayıları "Sorumluluk" için .73, "Dostluk/Arkadaşlık" için .91, "Barışçı Olma" için ,80, "Sayg1" için ,88, "Dürüstlük" için ,75, "Hoşgörü" için ,79 olarak bulunmuştur. Ölçeğin tümü için kararllık katsayısı: ,87 bulunmuştur. (Dilmaç, 2007).

Beck Umutsuəluk Ölçeği. Beck, Weissman, Lester ve Trexler tarafindan 1974 yllinda geliştirilmiştir. Durak ve Palabıyıkoğlu tarafindan 2006 yllında Türkçeye uyarlanmıştır. BUÖ, 20 maddeden oluşan kendini değerlendirme türü bir ölçektir. Maddeler Doğru - Yanlış şeklinde cevaplanmaktadır. Ölçek okuma yazması olanlara, çocuklara ve gençlere uygulanabilmektedir Ölçeğin puan aralığı 0-20 arasındadır, cevap anahtar1 ile uyan her cevap 1, uymayan her cevapsa 0 puan almaktadir. 1-3-5-6-8-10-13-15-19, maddelere "yanlış" cevabı için, 2- 4-7-9-11-12-14-16-17-18-20, maddelere ise "doğru" cevab1 için 1 puan verilmektedir. Alınan puanlar yükseldikçe kişinin umutsuzluk seviyesinin de yükseldiği kabul görmektedir (Öner, 1997).

Beck Umutsuzluk Ölçeği’nin faktör yapısını araştıran pek çok çalışma yapılmıştır. Beck ve diğerleri (1974), ölçeğin "gelecekle alakalı duygular", 'motivasyon kaybı' ve "geleceğe dair beklentiler "olarak üç faktörle oluştuğunu ifade etmektedir. Shek (1993), ölçeğin "gelecek hakkında duygular", "motivasyon kaybı" ve "geleceğe ilişkin beklentiler" olmak üzere üç faktörden oluştuğunu öne sürmüştür. Ülkemizdeyse ölçeğin faktör yapısını araştıran iki çalışmaya ulaşılabilmiştir. Durak (1993), ölçeğin "gelecekle ilgili duygular ve beklentiler (1-3-7-11- 18.maddeler), "motivasyon kaybı" (2-4-9-12-14-16-17-20. maddeler) ve "umut" (5-6-8- 10-13-15-19.maddeler) olmak üzere üç faktörden oluştuğunu ifade etmiştir. Bu çalışmada faktörlerin varyansı açıklama oranı, "gelecekle ilgili duygular ve beklentiler" için \% 27.9, "motivasyon kaybı" için \% 8.1 ve "umut" faktörü için \% 6.6'dır. Faktör alt ölçekleri arasındaki korelasyonun ise, $\mathrm{r}=.48$ $(\mathrm{p}<.001)$ ile $\mathrm{r}=.59(\mathrm{p}<.001)$ arasında bulunduğu ortaya konmaktadır.

Derebaşı (1996) da yine ölçeğin üç faktör yapısı bulunduğuna bulguları arasında yer vermektedirler. Araç, ilk olarak Beck, Lester ve Trexler tarafindan, intihar girişiminde bulunan 294 hasta üstünde denenmiştir. Araştırmadan elde edilen Cronbach Alfa güvenirlik katsayısının 0,93 olduğu, madde-toplam puan korelâsyonlarının ise 0.39 ile 0.76 arasında değiştiği görülmüştür. Aynı araştırmada 8 derecelik bir klinisyen değerlendirme formu kullanılmış ve iki ölçek arasındaki korelasyon katsayısı 0.62 olarak bulunmuştur. 59 depresif hasta üstünde Beck Depresyon Envanteri'nin 2. maddesi (umutsuzluk) ile korelasyonu 0.63 olarak belirlenmiştir (Savaşır ve Şahin, 1997).

Türkiye'de Beck Umutsuzluk Ölçeğinin geçerlik ve güvenirlik araştırması ilk olarak Gülten Seber tarafından, 1991 senesinde yapılmıştır. 107 kişilik örneklem üzerinde yapılan araştırmada güvenirlik için saptanan Cronbach Alfa katsayısı a $=0.86$, test-tekrar test sonucu elde edilen Pearson momentleri çarpımı korelasyonu ise $r=0.73$ olarak bulunmuştur (Savaşır ve Şahin,1997).

Durak (1993), ölçeğin geçerliğinin belirlenmesi maksadıyla yürüttüğü araştırmasında BUÖ hem normal kişiler için hem de psikolojik ve fizyolojik süreğen rahatsızlığı bulunan kişilerde umutsuzluğu ölçme maksadıyla geçerli ve güvenilir olduğunu belirtmiştir. Durak araştırmasında, ölçeği 373 kişi üstünde uygulamış, bütün örneklem için Alpha güvenirlik katsayısını a $=0,85$ şeklinde bulmuştur. İki yarım test tekniğiyle pek çok kere daha hesaplanmış güvenirlik katsayısı bütün örneklem için $r=0.85(p<0,001)$ şeklinde saptanmıştır. Ölçeğin her bir maddesinden elde edilen puanlarla bütün ölçekten elde edilen puanlar arasındaki madde - test korelasyon katsayları $r=.31 \quad(p<0.001)$ ile $r=0.67 \quad(p<0.001)$ arasinda bulunmuştur. Ölçeğin geçerliğini test etmek maksadıyla maddeler t-testi ile karşılaştırılmışlar ve anlamlı düzeyde $(\mathrm{p}<0.001)$ ayırt edici bulunmuşlardır.

California Yılmaə̌llk Değerlendirme Ölçeği Lise Versiyonu. California Yılmazlık Değerlendirme Ölçeği (CYDÖ) Lise Versiyonu, WestEd ve Duerr Evaluation Resources tarafindan 1999 yllında geliştirilmiş, Özcan(2005) tarafindan Türkçe'ye uyarlanmıştır. Ölçek sekiz alt ölçeğin bulunduğu 36 maddeden oluşmaktadır ve yanıtlar dört seçeneklidir. (1) Tamamen doğru değil, (2) Biraz doğru, (3) Çok doğru, (4) Oldukça çok doğru. Ölçekte her özellikten alınmış olan ortalama puan değerlendirmeye alınırken; 2'nin alı düşük; 2 ile 3 arası orta; 3 ve üzeri yüksek kabul edilmektedir (Constantine, Benard ve Diaz, 1999; Constantine ve Benard, 2001 Akt: Özcan, 2005).

1. Alt Ölçek/ Toplumdaki Koruyucu İlişkiler ve Yüksek Beklentiler: Öğrencinin okul ve ev dışında çevresindeki herhangi bir yetişkin tarafindan ilgilenildiğini, desteklendiğini, düşünülüp güvenildiğini, önemsendiğini; aynı zamanda öğrencinin de okul ve ev dişında güvendiği bir yetişkinin olduğunu ölçen maddelerden oluşur. Bu maddeler 7-8-9-10-11-12. maddelerdir. 
2. Alt Ölçek/ Ailedeki Koruyucu İlişkiler, Yüksek Beklentiler ve Anlamlı Katılımlar için Olanaklar: Öğrencinin aile içinde ana-baba veya ailedeki diğer bir yetişkin tarafindan önemsenip değer verildiğini, ilgilenildiğini, güvenildiğini ölçen maddelerden oluşur. Bu alt ölçek 30-31-32-33-34-35-36 nolu maddelerdir.

3. Alt Ölçek/ Okuldaki Koruyucu İlişkiler ve Yüksek Beklentiler: Öğrencinin devam ettiği okulda, bir öğretmeni veya başka bir büyüğünün, onunla, ilgilendiğini, önemseyip değer verdiğini, güvendiğini belirten maddelerden oluşur. Bu maddelerin numaraları 1-2-3-4-5-6'dir.

4. Alt Ölçek/ Arkadaş Grubundaki Koruyucu İlişkiler: Bu alt ölçek, öğrencinin yakın ilişki kurup sorunlarını paylaşabileceği ve kendisine yardımcı olabilecek yaşı bir arkadaşının olup olmadığını belirten maddelerden oluşur. Bu maddeler 27-28-29 nolu maddelerdir.

5. Alt Ölçek/ Öz Yetkinlik-Öz Farkındalık: Öğrencinin sorunlarıyla baş edebildiği, isterse birçok şeyi yapabileceğine olan inancını, kendine güvenini, neden-sonuç ilişkisi kurabildiğini, kendi duygularının ne derece farkında olduğunu ölçer. 17-18- 19-25 ve 26. maddelerden oluşur.

6. Alt Ölçek/ Empati: Öğrencinin çevresindeki insanlarla ilgili olup onlarla ne derece empati kurabildiğini ölçer. 20-21 ve 23. maddelerden oluşur.

7. Alt Ölçek/ Amaçlar Ve Özlemler: Öğrencinin, geleceğiyle ilgili amaçları olan ve bunlarla ilgili plan yapan biri olup olmadığını ölçen maddelerden oluşur. Bu maddelerin numarası 13-14 ve 24'dür.

8. Alt Ölçek/ Problem Çözme: Öğrencinin sorunlarını ne şekilde çözeceği konusunda yeterli olup olmadığını ölçen maddelerden oluşur. Bu maddeler 15-16 ve 22 numaralı maddelerdir.

Sekiz alt ölçeğin tümünde, alınan puan arttıkça ölçeğin ifade ettiği özellikler artmaktadır.

CYDÖ’nin güvenirliğiyle ilgili Alfa değerleri 1. Alt ölçek için (.85), 2.alt ölçek için (.81), 3.alt ölçek için (.77), 4.alt ölçek için (.89), 5.alt ölçek için (.66), 6.alt ölçek için (.71), 7.alt ölçek için (.61), 8.alt ölçek için (.61)'dir. Ölçekte yer alan bütün maddeler için madde-toplam korelasyonları (.28) ile (.52) arasında değişmekte ve $\mathrm{t}$-değeri anlamlı $(\mathrm{p}<.001)$ çıkmaktadır (Özcan, 2005).

\section{Verilerin Analizi}

Öncelikle öğrencilere çalışma hakkında bilgi verilmiş ve araştırmaya gönüllü olarak katılmak isteyen öğrencilere uygulanmıştır. Uygulama öğrencilere ders dışı saatlerde sınıf ortamında yapılmıştır. Verilerin sadece bilimsel araştırma kapsamında ve anonim olarak kullanılacağı konusunda katılımcılara bilgi verilmiştir. Araştırma "Yapısal Eşitlik Modeli” ne göre AMOS 19 Programı kullanılarak analiz edilmiştir.

\section{Bulgular}

Elde edilmiş olan son modelde $\left(\mathrm{X}^{2}=201.711, \mathrm{df}=71, p<.001\right.$ ) altı exogenus, (sorumluluk, dostluk/arkadaşlık, barışçı olma, sayg1, dürüstlük ve hoşgörü) on bir endogenous (toplum, aile, okul, arkadaş, öz yetkinlik, empati, amaçlar, problem çözme, gelecek, motivasyon ve umut) veri bulunmaktadır. Modelde gösterilen yolların her biri istatistiksel olarak anlamlı bulunmuştur. The Bentler-Bonettnormed fit index (NFI), The'Tucker-Lewiscoefficient fit index (TLI) ve diğer uyum indeksleri modelin oldukça iyi uyumlu olduğunu göstermiştir (Tablo 1). Modelde yer alan endogenous verileri arasındaki iki yönlü korelasyonların her biri yüksek değerlere sahiptir ve istatistiksel olarak anlamlıdır. Bu durum, çalışmada kullanılan değerler ölçeğinin alt boyutlarının sahip olduğu korelasyon değerlerinden de etkilenmektedir.

Tablo 1. Yapısal Eşitlik Modelinin Uyumuna İliskin İstatistiksel Değerler

\begin{tabular}{cccc}
\hline Ölçüm & İy Uyum & Kabul Edilebilir Uyum & Modelin Uyum Índeksi Değerleri \\
\hline X2/sd) & $\leq 3$ & $\leq 4-5$ & 2.84 \\
RMSEA & $\leq 0.05$ & $0.06-0.08$ & 0.07 \\
SRMR & $\leq 0.05$ & $0.06-0.08$ & 0.07 \\
NFI & $\geq 0.95$ & $0.94-0.90$ & 0.93 \\
CFI & $\geq 0.97$ & 0.95 & 0.94 \\
GFI & $\geq 0.90$ & $0.89-0.85$ & 0.88 \\
AGFI & $\geq 0.90$ & $0.89-0.85$ & 0.87 \\
TLI & $\geq 0.95$ & $0.94-0.90$ & 0.92 \\
\hline
\end{tabular}


Tablo 1'de yer alan uyum değerleri ele alındığında, $\mathrm{X}^{2} / \mathrm{sd}=2.84$, RMSEA $=0.07$, SRMR $=0.07$, NFI $=0.93, \mathrm{CFI}=0.94, \mathrm{GFI}=0.88$, AGFI $=0.87$ ve TLI $=0.92$, olarak bulunmuştur. Genel biçimde modelin arzulanan seviyede uyum değerlerine sahip olduğu anlaşılmaktadır (Bollen, 1989; Browne ve Cudeck, 1993; Byrne, 2010; Hu ve Bentler, 1999; Kline, 2011; Tanaka ve Huba, 1985). Test edilen tek faktörlü model Şekil 1'de gösterilmiştir. Modelde gösterilen tüm yollar 0.001 düzeyinde anlamlı bulunmuştur.

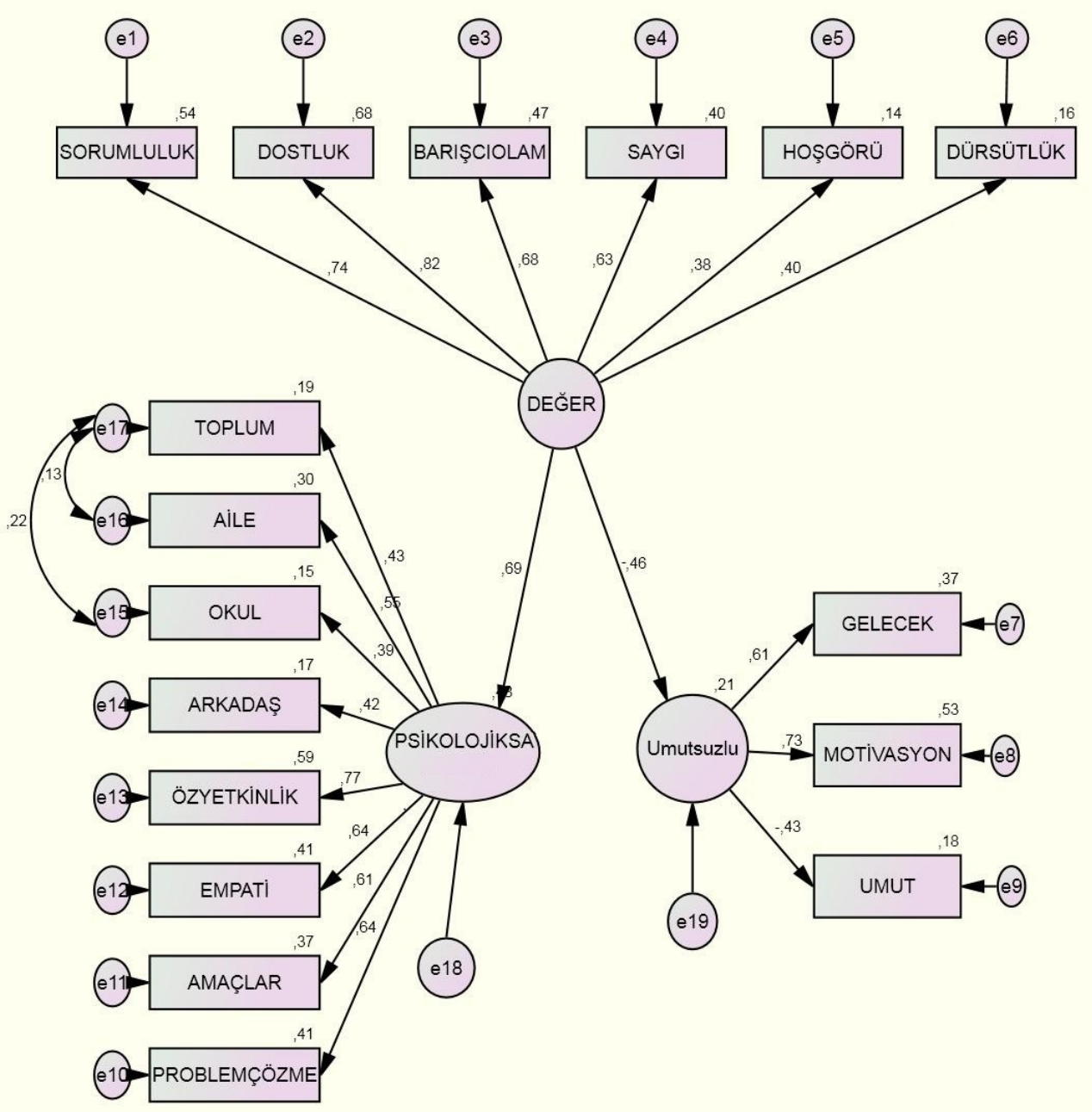

Şekil 1. Modele Ilişkin Yol Analizi

Tablo 2. Ergenlerin Sahip Olduklar Değerler İle Psikolojik Sağlamllk ve Umutsuəluk Düzeyleri Arasindaki Asindaki Yordayucı Illiskilerine Yönelik. Model

\begin{tabular}{llcccccc}
\hline Yordayıcı Değisken & Bağıml Değisken & Toplam Etki & $\begin{array}{c}\text { Doğrudan } \\
\text { Etki }\end{array}$ & $\begin{array}{c}\text { Dolaylh } \\
\text { Etki }\end{array}$ & $\begin{array}{c}\text { Standart } \\
\text { Hata }\end{array}$ & $\begin{array}{c}\text { Kritik } \\
\text { Değer }\end{array}$ \\
\hline Değer & Psikolojik Sağlamlık & .069 & .069 & 0 & 0.47 & $5.14^{*}$ \\
Değer & Umutsuzluk & -.046 & -.046 & 0 & 0.35 & $-2.19^{*}$ \\
\hline
\end{tabular}

${ }^{a}$ Toplam etki $=$ Doğrudan etki + Dolaylı etki, ${ }^{*} p<0.01,{ }^{* *} p<0.05$.

Tablo incelendiğinde, psikolojik sağlamlığı etkileyen en önemli bağımsız değişkenin ( $\mathrm{t}=5.14, p<0.01)$ değerler olduğu görülmektedir. Bu faktöre ilişkin bağlantı katsay1 değeri $\beta=069$ olarak bulunmuştur. Ergenlerin sahip oldukları değerler ile psikolojik sağlamlık arasındaki yordayıcı ilişskilere bakııldığında, pozitif yönlü doğrusal bir ilişki olduğu sonucuna ulaşılmıştır. Bir başka deyişle elde edilmiş olan bulgular, ergenlerin sahip oldukları değerler arttıkça, psikolojik sağlamlık düzeylerinin de artacağı ortaya çıkmıştır. 
Modelde umutsuzluk düzeylerini etkileyen en mühim bağımsız değişkenin ( $\mathrm{t}=-3.92, p<0.01)$ değerler olduğu görülmüştür. Bu faktöre ilişkin bağlantı katsayı değeri $\beta=-0.46$ olarak belirlenmiştir. Ergenlerin, sahip oldukları değerler ile umutsuzluk düzeyleri arasındaki yordayıcı ilişkilere bakıldığında, negatif yönlü doğrusal bir ilişki olduğu saptanmıştır. Bir başka ifadeyle elde edilmiş olan bulgular, ergenlerin sahip oldukları değerlerin arttıkça, umutsuzluk düzeylerinin de azalacağını ortaya koymaktadır.

\section{Tartışma, Sonuç ve Öneriler}

Bu kısımda ergenlerin sahip oldukları değerler, umutsuzluk düzeyleri ve psikolojik sağlamlık düzeyleri arasındaki yordayıcı ilişkilerin araştırılması sonucu ulaşılan bulguların tartışması ve yorumu yapılmıstır.

Araştırmadan çıkarılan bulgulara bakıldığında, psikolojik sağlamlı̆ga etki eden en mühim bağımsız değişkenin değerler olduğu görülmüştür. Elde edilen sonuç ergenlerin psikolojik sağlamlıklarının, onların sahip olduğu değerlere göre farklılık göstereceğini ortaya koymaktadır. Bir başka deyişle elde edilmiş olan bulgulara göre, ergenlerin sahip oldukları değerle arttıkça, psikolojik sağlamlık seviyelerinin de artacağı ortaya konmuştur. Literatürde ergenlerin sahip oldukları değerler ile psikolojik sağlamlıklarının birlikte ele alındığı sınırlı sayıda çalışma vardır.

Aynı zamanda araştırma sonuçlarına göre ergenlerin umutsuzluk düzeylerini etki eden en mühim bağımsız değişkenin değerler olduğu görülmüştür. Bir başka deyişle elde edilmiş olan bulguların doğrultusunda, ergenlerin sahip oldukları değerlerin artması ile umutsuzluk düzeylerinin azalacağı ortaya çıkmıştır. Literatürde ergenlerin sahip oldukları değerler ile umutsuzlukları arasında var olan ilişkinin incelendiği sınırlı sayıda çalışma vardır.

Bhana ve Bachoo (2011) araştırmasında bireylerin sahip olduğu değerler ve inanç sistemlerinin; bireysel yılmazlık ve aile yılmazlığını etkilediğini ortaya koymuştur. Benzies ve Mychasiuk'de (2009) bireysel yılmazlık ve aile yılmazlığını değerler, maneviyat-inanç yapısı, özgüven, etkili başa çıkabilme becerileri gibi değişkenlerin etkilediğini belirtmiştir. (Tosun, 2014, s. 2)

Ağırkan ve Kağan (2017) tarafından gerçekleştirilen Üniversite Öğrencilerinin Değer Yönelimleri ile Psikolojik Dayanıklılık Düzeyleri Arasındaki İlişki adlı çalışmada üniversite öğrencilerinin sahip oldukları Uyarılma, Özyönelim-Düşünce, Evrenselcilik-Hoşgörü, Başarı, Güç-Kaynaklar, Güvenlik-Toplumsal ve Evrenselcilik-Doğa değer tiplerinin psikolojik dayanıklılık seviyelerini anlamlı biçimde yordadığı sonucuna ulaşmıştır. Psikolojik açıdan dayanıklı olan kişilerin özellikleri incelendiğinde kuvvetli bir özyeterlik hissiyle karşı karşıya kalınan yeni hallere kolaylıkla uyum gösterme yeteneğine sahip olmaları göze çarpmaktadır (Haynes, 2005 Akt. Ağırkan ve Kağan, 2017, s. 238). Alanyazındaki çalışmalar incelendiğindeyse psikolojik açıdan dayanıklı kişilerin öngörülü olma, hedefe ulaşma, liderlik, araştırmacılık, girişimcilik, güçlü olma, optimist olma ve iletişim kurma gibi özellikleriyle psikolojik dayanıklılık seviyeleri arasında pozitif yönlü ilişkilerin olduğu (Bolat, 2013), öte yandan yenilik ve farklılık arayışına karşılık kaçınmayı gerekli kılan sosyal kaygı durumlanı ile psikolojik dayanıklılık seviyeleri arasında negatif yönlü ilişkilerin olduğu (Atarbay, 2017) yolundaki araştırmalara rastlanmaktadır (Ağırkan ve Kağan, 2017, s. 239). Araştırmanın sonucunda elde edilmiş olan bu bulgulardan yola çıarak, üniversite öğrencilerinin "heyecan duyma, yenilik ve değişiklik arayışı" şeklinde de ifade edilebilen Uyarılma değer tipine sahip olmalarının psikolojik dayanıklılık seviyelerini arttırdığ1 sonucuna ulaşılmıştır.

Araştırmanın bir diğer sonucuna göreyse Özyönelim-Düşünce değer tipinin psikolojik dayanıklilığı yordadığ1 görülmüştür. Literatürde yer bulmuş araştırmalar incelendiğinde mantıklı karar verebilme stratejisinin psikolojik dayanıklilık seviyesinde artışa neden olduğu (Tonga, 2014), benlik saygısı ile psikolojik dayanıklılık seviyeleri arasındaysa pozitif yönlü anlamlı bir ilişkinin var olduğu (Sarıkaya, 2015), dıştan denetimli olma halindeyse psikolojik dayanıklılık seviyesinin azalması (Karaırmak ve Siviş-Çetinkaya, 2011) şeklinde çalışma bulgularına ulaşılmaktadır (Ağırkan ve Kağan, 2017, s. 239).

Psikolojik dayanıklılık kavramını yordayan bir başka değer tipi Evrenselcilik-Hoşgörü’dür. Psikolojik açıdan dayanıklı kişilerin özellikleri incelendiğinde arkadaş olma ve mevcut arkadaşlı̆̆ı geliştirme yetisiyle çevresindeki kişilerle pozitif ilişkiler kurma kabiliyetine sahip oldukları gözlenmektedir (Haynes, 2005). Literatürdeki araştırmalar sosyal ilginin psikolojik dayanıklllı̆ı anlamlı biçimde yordadığını (Özbay ve Kayac1, 2015), sosyal hizmet alanında yapılmış olan araştırmaların kişilerde psikolojik dayanıklılık düzeyini yükselttiği (Palma-Garcia ve Homrados-Mendieta, 2014) yönündeki çalışma bulgularının varlı̆̆ı göze çarpmaktadır (Ağırkan ve Kağan, 2017, s. 239). 
Başarı değer tipinin psikolojik dayanıklılık durumunu yordadığı ifade edilebilir. Psikolojik açıdan dayanıklı olan kişilerin özellikleri incelendiğinde bu kişilerin başarıyı aşırı biçimde arzuladıkları görülmektedir (Haynes, 2005). Literatürdeki araştırmalar incelendiğinde kişisel başarı duygusunun azalması durumunu da içine alan tükenmişlik algısı ve psikolojik dayanıklllğı̆n birbirlerini olumsuz yönde etkiledikleri (Akyazı ve Özsoy, 2015), duygusal zekânın psikolojik dayanıklılık üstünde anlamlı bir yordayıcı olduğu (Ergün, 2016; Özer, 2013) yönündeki çalışma bulgularına ulaşılmaktadır (Ağırkan ve Kağan, 2017, s. 239).

Evrenselcilik-Doğa değer tipinin psikolojik dayanıklılık kavramını yordadığı sonucuna varılmıştır. Psikolojik açıdan dayanıklı olan kișilerin özellikleri incelendiğinde kişinin yaşadığı sosyal çevreyi etrafına faydası olacak şekilde biçimlendirme ve işe koşma yeterliğine sahip oldukları gözlenmektedir (Haynes, 2005 Akt: Ağırkan ve Kağan, 2017, s. 239). Araştırmanın bu sonucundan yola çıarak, üniversite öğrencilerinin "yaşadığ1 doğal çevrenin korunmasına yönelik çabası" şeklinde de ortaya konan Evrenselcilik-Doğa değer tipini kendilerinde barındırmalarının psikolojik dayanıklılık seviyelerini arttırmada rol aldığı söylenebilir.

Psikolojik dayanıklılığın bir başka yordayanı Güç-Kaynaklar değer tipidir. Literatürdeki araştırmalar incelendiğinde sinir katsayıları yüksek bireylerin psikolojik dayanıklllık seviyelerini düşük olduğu (Çetin, Yeloğlu ve Basım, 2015; Özer, 2013; Palma-Garcia ve Homrados-Mendieta, 2014; Fayombo, 2010), yaşamları boyunca pek çok negatif tecrübe edinenlerin psikolojik dayanıkllık seviyeleri ile kendi duygularının farkına varabilme, duygularını ifade edebilme ve duyguların kontrol edebilme seviyeleri arasında anlamlı düzeyde ilişkiler olduğu (Armstrong, Galligan ve Critchley, 2011) yönündeki çalışma bulgularına ulaşılmaktadır (Ağırkan ve Kağan, 2017, s. 239).

Araştırmanın başka bir neticesine bakıldığında Güvenlik-Toplumsal değer tipinin psikolojik dayanıklılık kavramını yordadığı belirlenmiştir. Literatürdeki araştırmalar incelendiğinde psikolojik hal ve algılanan etkiler gibi içsel etmenlerin yanı sıra sosyoekonomik durumun kötü olması, harpler ve tabi felaketler, toplumsal şiddet ve ailevi sıkıntılar, evsizlik ve benzeri dış kaynaklı etmenlerin de psikolojik dayanıklilğga etki ettiği görülmüştür. Bu bağlamda güçlük, bunalım veya afet beklentisi şeklinde ifade edilen riskli hallerin söz konusu olmadığı hallerde psikolojik dayanıklılık kavramının gündeme gelmesinin söz konusu olmadığı ifade edilebilir (Erarslan, 2014 Akt: Ağırkan ve Kağan, 2017, s. 240). Bir başka deyişle kişilerin onları negatif hissettiren stres verici etkilerle karşı karşıya kaldıklarında koruyucu etmenleri harekete geçirmeleri, direnç gösterebilmeleri ve psikolojik dayanıklılık tavrını ortaya koyabilmeleri için öncelikle ortamda çevresel risk etmenlerinin olması lazımdır (Karaırmak ve Siviş-Çetinkaya, 2011, s. 34).

Sonuç olarak çalışmadan elde edilmiş psikolojik dayanıklılıkla bağlantılı olan değer yönelimlerinin psikolojik dayanıklılık kavramının bileşenlerini bir araya getiren risk etmenleri, koruyucu etmenler ve pozitif sonuçlar ile de tutarlı olduğu sonucuna varılmıştır (Kobasa, Maddi ve Courington, 1981). Çalışmadan elde edilmiş olan sonuçlar çalışmamızda ortaya koyduğumuz sonuçları destekler niteliktedir.

Ağır (2017) Yaşam kalitesi, Değerler ve Umut-Umutsuzluk adlı çalışmasında bireylerin yaşam kalitesi, bireylerin yaşam değerleri ile umut-umutsuzluk düzeylerini irdelemeyi amaçlamıştır. Bu bağlamda objektif ve subjektif kriterler açısından farklı yaşam kalitesi düzeylerindeki bireylerin değerleri ve yaşama karşı bağılılı duygularının göstergesi olarak kabul edilebilecek umut- umutsuzluk duygularının nasıl olabileceğine ilişkin bir analiz yapmış ve toplumsal gelişme açısından bu dinamiklerin değerlendirmiştir. En basit șekilde "bireyin hayatını genel anlamda düzenleyen ilkeler topluluğu olarak" değerler, bir şeyin istenebilir veya istenemez olduğu ile ilgili inanç olarak, düşünce, duygu ve davranışlara yön verebilmektedir (Güngör, 2000: 27). Dolayısıyla, bireyin yaşamını kaliteli ya da kalitesiz algılaması ve bu değerlendirmelere bağlı olarak yaşamından memnuniyet duyup duymamas1, kendisini yaşama bağlayan temel değerlerle ilişkilendirilebilir. Bu bağlamda değerlerin, kişiyi eylemde bulunmak için motive eden ve iyilik hissi veren bir özellik olarak, kişinin yaşamını zenginleştiren ve onu güdüleyen bir güç olarak kabul edilen umut duygusuna da rehberlik etmesi beklenebilir. (Hökelekli, 2010, s. 5). Bir başka ifade ile bireyin, günlük yaşamında fiziksel ve ruhsal olarak kendini iyi hissetmesi, ekonomik güvenlik ve sosyal ilişkilerini yeterli bulması, yaşam kalitesi ve değerleri bağlamında umut duygusunu ve hayata bağlılı̆̆ını arttırabilecektir. Tam tersi durum ise umutsuzluk duygusuna yol açabilecektir. Bu doğrultuda umut ve umutsuzlukla ilgili yaşama dair olumlu/olumsuz beklentileri, yaşam kalitesi ile yaşam değerlerinin sonucu olarak değerlendirmek mümkündür. Bireyin, sahip olduğu değerler ile geçmiş, şimdi ve gelecek bağlamında yaşamına ilişkin yaptığı olumlu/olumsuz yorumları, geleceğe ilişkin umut ya da umutsuzluk düşüncesi ile ilişkilendirebilmektedir (Durak, 1994). 
$\mathrm{Bu}$ durumu bir süreç olarak ele alındığındaysa birbirlerini etkileyen dinamikler olarak, umutsuz bir bireyin, giderek yaşam kalitesini yükseltmek için göstereceği çabanın azalacağı ve yaşam kalitesinin düşük olması ile ilgili atıfta bulunduğu etmenlerin farklılaşabileceği, sahip olduğu değerleri koruma ve muhafaza etme konusunda sorun yaşayabileceği, kendisine ve topluma ilişkin düşünce, duygu ve davranışlarının değişebileceğini sonucuna ulaşılabilir (Ağır, 2017, s. 100). Bu kavramların farklı boyutlarda ele alındığ1 araştırma sonuçları, toplumsal gelişme ve değişme sürecinde her iki dinamiğin önemine dikkat çekmektedir. İnsanca bir yaşam tarzının temel koşulları içerisinde, yaşamı anlamlı kılacak değerlere bağlanarak geleceğe ilişkin olumlu duygular ile güven içinde yaşayabilmek temel insan hakkıdır. Dünya'da 2000 'li yıllardan sonraki değişmeler göz önüne alındığında yalnızca gelişme aşamasında olan ülkelerin penceresinden değil gelişmiş ülkelerin penceresinden de yaşam kalitesi ve değerlerin sağlıklı bir toplum için vazgeçilmez temel unsurlar olarak değerlendirildiği ve bu değerlendirmenin ilerleme amacının ötesinde sağlıklı, gelecek nesillerin yaşam güvencesi olarak ele alındığı görülmektedir. Bu bağlamda toplumların yaşam kalitesine vereceği önemin bireylerin olumlu değerler geliştirmesinin yanı sıra yalnızca bireysel değil toplumsal umut duygusunun gelişimi ve ilerleme yönünde toplumsal sorumluluk bilinci ve davranışları için etkili olabileceği düşünülmektedir (Ağır, 2017, s. 100).

Bulut ve Dilmaç (2018) Üniversite Öğrencilerinin Sahip Olduğu Değerler Psikolojik İyi Oluş ve Mutluluk Düzeyleri Arasındaki Yordayıcı İlişkiler adlı çalışmasında üniversite öğrencilerinin sahip olduğu değerler ve psikolojik açıdan iyi olma halleri arasındaki yordayıcı ilişkileri incelemiş, pozitif yönde doğrusal bir ilişki olduğu sonucuna varmıştır. Bir diğer deyişle elde edilmiş olan bulgular, üniversite öğrencilerinin sahip oldukları değerler arttıkça psikolojik iyi oluş seviyelerinin de artacağını ortaya koymuştur. Yapılan benzer çalışmalar incelendiğinde, Telef, Uzman ve Ergün'ün (2013) öğretmen adaylarının psikolojik iyi oluşları ve sahip olduğu değerlerden başarı, hazcilık, özyönelim, evrenselcilik, iyilikseverlik, uyma ve güvenlik arasında pozitif yönde anlamlı ilişkiler olduğu sonucuna ulaşılmıstır. Özellikle öz aşkınlık değer boyutunun psikolojik iyi oluşu halini anlamlı biçimde yordadığı görülmüştür (Bulut ve Dilmaç, 2018, s. $362)$.

Bir diğer çalışma, ahlaki değerlere (ahlaki olgunluk) sahip olmanın psikolojik iyi oluşu ne yönde yordadığını ortaya koymak için yapılmıştır. Farhan, Dasti ve Khan (2015), tarafından üniversite öğrencilerine yönelik gerçekleştirilen araştırmaya göre ahlaki olgunluğu işaret eden ahlaki değerlere sahip olan bireyler yüksek derecede psikolojik iyi oluş bildirmiştir (Bulut ve Dilmaç, 2018). Bunun yanında sevgi şefkat ve minnettarlık değerlerinin hem ruh sağlığına hem de fiziksel sağlığa olumlu etkilerinin olduğunu McCraty ve Childre (2002) çalışmalarıyla ortaya koymuştur. Yaşamın güçlükleriyle başa çıkmada bireye yardımcı olan inanç, aynı zamanda bireyin hayatı anlamlandırmasına da yardımcı olmaktadır (Tuzgöl- Dost, 2007 Akt: Bulut ve Dilmaç, 2018, s. 362). Dini inancın (Balc1, 2011; Tuzgöl- Dost, 2007) ve dini yönelimin (Göcen, 2013) ibadet etmenin (Kaya ve Küçük, 2017) psikolojik iyi oluşla ve yaşamı anlamlandırmayla doğrudan ilişkili olduğu sonucuna ulaşmış çalışmalar bulunmaktadır (Bulut ve Dilmaç, 2018: 362). Bunun yanında psikolojik iyi oluşla şükretmenin çeşitli boyutları (karşılaştırmalı şükür, memnuniyetle ilgili olan şükür, aileyle ilgili olan şükür, ibadetle ilgili olan şükür) arasında anlamlı bir ilişki olduğunu Göcen (2012), çalsşmasiyla ortaya koyulmuştur. Lun ve Bond (2013), 2005-2008 senelerinde 57 ülkeden 82.982 katılımcıdan oluşan örneklemiyle gerçekleştirdiği araştırmada maneviyat, dindarlık ve yaşam memnuniyeti arasındaki ilişkinin pozitif yönde olduğu bilgisine ulaşmıstır. Sonuç itibariyle çalşsma, dindarlık ve maneviyatın yaşam memnuniyeti, iyi oluş ve mutluluk arasında pozitif yönde yordayıcı ilişkiler olduğunu tespit etmiştir (Bulut ve Dilmaç, 2018, s. 363).

Çetinkaya (2011) emekli bireylerin yaşam doyumunu etkileyen en önemli faktörlerin, sosyal destek ve öz-yeterlilik olduğunu ortaya koymuştur. Dilmaç, Deniz ve Yıldız (2011) öğretmen adaylarının sahip oldukları değerlerle psikolojik iyi oluş boyutlarından, benlik saygısı arasındaki ilişkiyi araştırmış ve söz konusu değişkenler arasında pozitif bir ilişkinin olduğunu ortaya koymuştur (Bulut ve Dilmaç, 2018, s. 364). Tüm bu sonuçlar çalışmamızı doğrudan veya dolaylı olarak destekler niteliktedir.

\section{Etik Beyan}

"Ergenlerin Umutsuzluk ve Psikolojik Sağlamlıklarının Sahip Oldukları Değerler Açısından İncelenmesi” başlıklı çalışmanın yazım sürecinde bilimsel, etik ve alıntı kurallarına uyulmuş; toplanan veriler üzerinde herhangi bir tahrifat yapılmamış ve bu çalışma herhangi başka bir akademik yayın ortamına değerlendirme için gönderilmemiştir. 


\section{Kaynakça}

Abramson, L. Y., Metalsky, G. I. ve Alloy, L. B. (1989). Hopelessness depression: A theory-based subtype of depression. Psychological Review, 96, 358-372.

Abela, J. R. Z. ve Seligman, M. E. P. (2000). The hopelessness theory of depression: A test of the diathesis-stress component in the inter-personal and achievement domains. Cognitive Therapy and Research, 24(4), 361-378.

Ağır, M. (2017). Yaşam kalitesi, değerler ve umut-umutsuzluk. Marmara Sosyal Arastırmalar Dergisi,11, 85-103.

Ağırkan M. ve Kağan M. (2017). Üniversite öğrencilerinin değer yönelimleri ile psikolojik dayanıklılık düzeyleri arasındaki ilişki. Eržincan Üniversitesi Eğitim Fakültesi Dergisi,19(3), 225-245.

Akbaba-Altun, S. (2003). Ĕgitim yönetimi ve değerler. Değerler Ĕğtimi Dergisi, 1(1), 7-18.

Aydın, M. (2003). Gençliğin değer algis1: Konya örneği. Değerler Ĕgitimi Dergisi, 1(3), 121-144.

Block, J. ve Kremen, A. M. (1996). IQ and ego-resiliency: Conceptual and empirical connections and seperateness. Journal of Personality and Social Psychology, 70(2), 349-361.

Bollen, K. A. (1989). Structural Equations with Latent Variables. NewYork: John Wiley and Sons.

Browne, M. W. ve Cudeck, R. (1993). Alternative ways of assessing model fit. In Bollen, K. A. \& Long, J. S. [Eds.]. Testing structural equation models. Newbury Park, CA: Sage. pp. 136-162.

Bulut, S. ve Dilmaç, B. (2018). Üniversite öğrencilerinin sahip olduğu değerler psikolojik iyi oluş ve mutluluk düzeyleri arasındaki yordayıcı ilişkiler. Uluslararası Toplum Araștırmalar Dergisi, 9(16), 351-374.

Büyüköztürk, Ş., Kılıç Çakmak, E., Akgün, Ö. E., Karadeniz, Ş. ve Demirel, F. (2008). Bilimsel araştırma yöntemleri (14. Baskı). Ankara: Pegem Yayınları.

Byrne, B. M. (2010). Structural equation modeling with AMOS: Basic concepts, applications, and programming (2nd Edition). Routledge Taylor \& Francis Group.

Chang, E. C., D'Zurilla T. J. ve Mayder-Olivares, A. (1994). Assesing the dimensionality of optimism and pessimism using multimeasure approach. Cognitive Therapy and Research, 18, 143-160.

Çelikel, F. Ç. ve Erkorkmaz, Ü. (2008). Üniversite öğrencilerinde depresif belirtiler ve umutsuzluk düzeyleri ile ilişkili etmenler. Nöropsikiyatri Arșivi, 45, 122-129.

Derebaş1, I. (1996). Beck umutsuұ̨luk ölçeğinin Ege üniversitesi ögrencileri üzerinde geliştirilmesi (Yüksek lisans tezi). Ege Üniversitesi Sosyal Bilimler Enstitüsü, İzmir.

Dilmaç B. (2007). Bir grup fen lisesi ögrencisine verilen insani değerler eğitiminin insani değerler ölçĕ̆i ile sınanması (Doktora Tezi). Selçuk Üniversitesi, Konya.

Dilmaç, B., Bozgeyikli, H. ve Çıkılı, Y. (2008). Öğretmen adaylarının değer algılarının farklı değişkenler açısından incelenmesi. Değerler Eğitimi Dergisi, 6(16), 69-91.

Durak, A. (1993). Beck umutsu₹luk ölçegi’nin geçerliği üzerine bir çalışma (Yüksek Lisans Tezi). Ankara Üniversitesi, Sosyal Bilimler Enstitüsü, Ankara.

Durak, A (1994). Beck umutsuzluk ölçeği (BUÖ) geçerlik ve güvenirlik çalışması. Türk Psikoloji Dergisi, 9, 1-11.

Durmuş, Ç. (1996). Değerlerin meslek grupları açısından incelenmesi (Yüksek Lisans Tezi). Marmara Üniversitesi, Sosyal Bilimleri Enstitüsü, İstanbul.

Eminağaoğlu, N. (2006). Güc kossullarda yasayan sokak çocuklarnnda dayanıklulk (Sağlamlık) (Doktora Tezi). Ege Üniversitesi, İzmir.

Gizir, C. A. (2007). Psikolojik sağlamlık, risk faktörleri ve koruyucu faktörler üzerine bir derleme çalışması. Türk Psikolojik Danısma ve Rehberlik Dergisi, 3(28), 113-128.

Gökçe, B. (1994). Toplumsal değişim sürecinde gecekondu ailesi. Aile Kurultayı Değişim Sürecinde Aile: Toplumsal Kahtım ve Demokratik Değerler. Ankara: Başbakanlık Aile Araştırma Kurumu Başkanlığı.

Güngör, E. (1993). Değerler psikolojïi üzerinde araștırmalar. İstanbul: Ötüken Neşriyat.

Güngör, E. (2000). Değerler psikolojisi üzerine araștırmalar. İstanbul: Ötüken Neşriyat.

Hoşoğlu, R., Fırıncı Kodaz, A., Yılmaz Bingöl, T. ve Vural Batık, M. (2018). Öğretmen adaylarında psikolojik sağlamlık. Uluslararası Toplum Arastırmaları Dergisi, 8(14), 217-239.

Hökelekli, H. (2010). Modern eğitimde yeni bir paradigma: değerler eğitimi. Eğgitime Bakış Ĕ̆itim-Öğretim ve Bilim Arasttrmalar Dergisi, 6(18), 4-10.

Hu, L. ve Bentler, P. (1999). Cutoff criteria for fit indices in covariance structure analysis: conventional criteria versus new alternatives. Structural Equation Modeling, 6, 1-55.

Karaırmak, Ö. ve Siviş-Çetinkaya, R. (2009). Deprem deneyimini yaşamış yetişkinlerin bağlanma stilleri ve psikolojik dayanıklılıkları arasındaki ilişki. XVII. Ulusal Eğitim Bilimleri Kurultayı Kitapç̆̆̆ içinde (s.74-75). Ege Üniversitesi.

Kline, R. B. (2011). Principles and practice of structural equation modeling. New York: Guilford Press.

Kobasa, S. C., Maddi, S. R. ve Courington, S. (1981). Personality and constitution as mediators in the stress-illness relationship. Journal of Health and Social Behavior, 22(4), 368-378. doi: http://dx.doi.org/10.2307/2136678

Luthar, S. ve Cicchetti, D. (2000). The construct of resilience: Implications for interventions and social policies. Development and Psychopathology, 12, 857-885.

Oktay, A. S. (2007). İslam düşüncesinde ahlâkî değerler ve bunların global ahlâka etkileri. Değerler ve Eğitimi Uluslararası Sempozyumu (İstanbul, 26- 28 Kasim 2004), İstanbul: DEM.

Osterling, K. L. ve Hines, A. M. (2006). Mentoring adolescent foster youth: Promoting resilience during develop mental transitions. Child and Family Social Work, 11, 242-253. 
Öner, N. (1997). Türkive de kullanulan psikolojik testler: bir bașvuru kaynă̆ı. İstanbul: Boğaziçi Üniversitesi Yayınları.

Özcan, B. (2005). Anne-babalar boșanmıs ve anne-babalar birlikte olan lise ögrencilerinin ynlmąlık özellikleri ve koruyucu faktörler açısından karşılaştırılması (Yüksek Lisans Tezi). Ankara Üniversitesi, Eğitim Bilimleri Enstitüsü, Ankara.

Özmen, D., Dündar, P. E., Çetinkaya, A. Ç., Taşkın, O., \& Özmen, E. (2008). Lise öğrencilerinde umutsuzluk ve umutsuzluk düzeyini etkileyen etkenler, Anadolu Psikiyatri Dergisi, 9, 8-15.

Rutter, M. (1987). Psychosocial resilience and protective mechanism. Journal of Orthopsychiatry, 57(3), 316-331.

Savaşır, I. ve Şahin, N. H. (1997). Bilişsel-davranış̧ terapilerde değerlendirmede sık kullanılan ölçekler. Ankara: Türk Psikologlar Derneği Yayınları.

Shek, D. (1993). Measurement of pessimism in Chinese adolescents: The Chinese hopelessness scale. Social Behavior and Personality: An international journal, 21, 107-120.

Simon, S. B., Howe, L. W. ve Kirschenbaum, H (1978). Values clarification: A bandbook of practical strategies for teachers and students. New York: A \& W Publishers.

Şahin, D. (2014). Öğretmelerin öz duyarlkelarmm psikolojik sağlamllk ve yaşam doyumu açısından incelenmesi (Yüksek Lisans Tezi). Karadeniz Teknik Üniversitesi, Trabzon, Türkiye.

Şengül, S. ve Güner, P. (2012). İlköğretim matematik öğretmenliği programına devam eden öğretmen adaylarının umutsuzluk düzeylerinin incelenmesi. X. Ulusal Fen Bilimleri ve Matematik Eğitimi Kongresi. Niğde: Niğde Üniversitesi.

Tanaka, J. S. ve Huba, G. J. (1985). A fit index for covariance structure models under arbitrary GLS estimation. British Journal of Mathematical and Statistical Psychology, 38, 197-201.

Timüçin, A. (1994). Felsefe sö̊lü̈ü̈. İstanbul: BDS Yayınları.

Tosun, F. (2014). Evli çiftlerin sahip olduğu değerler, ynlmaz̨llk ve çatısma çöżme stilleri arasındaki yordayıc ilişkiler (Yüksek Lisans Tezi). Necmettin Erbakan Üniversitesi, Konya.

Üngüren, E. ve Ehtiyar, R. (2009). Türk ve Alman öğrencilerin umutsuzluk düzeylerinin karşılaştırılması ve umutsuzluk düzeylerini etkileyen faktörlerin belirlenmesi: Turizm eğitimi alan öğrenciler üzerinde bir araştırma. Journal of Yasar University, 4(14), 2093-2127.

Vinas Poch, F., Villar, E., Caparros, B., Cornella, M., Perez, I. ve Juan, J. (2004). Feelings of hopelessness in a Spanish University Population: Descriptive analysis and its relationship to adapting to university, depressive symptomatology and suicidal ideation. Social Psychiatry and Psychiatric Epidemiology, 39(4), 326-334.

Yıldırım, C. (2004). Ansiklopedik şăgdas felsefe sözlï̈̆̈̈, Ankara: Doruk Yayınları.

\section{EXTENDED ABSTRACT}

The general aim of the study is to examine the levels of hopelessness and psychological resilience of adolescents in terms of their values. The relational screening model, which is a sub-type of the general screening model, was conducted in the study. The study population consisted of adolescents who are currently studying in Konya between 2013-2014. The study group was selected by random cluster sampling among these adolescents.

The Human Values Scale; Beck Hopelessness Scale (BHS) and the California Resilience Rating Scale High School Version (SCD) were conducted. The study was analyzed by using AMOS 19 Program via "Structural Equation Model". As a result of the research findings it was determined that as the values of adolescents increased, their psychological stability levels would increase and their hopelessness levels decreased in a negative way.

Relational screening model was used in the study. Relational screening is performed to determine the relationship between two or more variables and to obtain clues about cause and effect (Büyüköztürk et al., 2008). Within the scope of the research, predictive relationships between the values of adolescents and the levels of hopelessness and psychological resilience are revealed.

The study group was selected with the appropriate sampling method from the study population consisting of adolescents studying at three different schools and at different grade levels in Konya province center and districts in 2013-2014 academic year. The study group consisted of 338 female and 250 male students. A total of 588 students participated in the study.

First of all, the students were informed about the study and applied to the students who wanted to participate voluntarily. The application was made to students in class environment during the extracurricular hours. Participants were informed that the data will be used only under scientific research and anonymously.

In the last model obtained $(\mathrm{X} 2=201.711, \mathrm{df}=71, \mathrm{p}<.001)$, six exogenous, eleven endogenous (community, family, school, friends, (responsibility, friendship / friendship, pacifism, respect, honesty and tolerance) self-competence, empathy, goals, problem solving, future, motivation and hope). Each of the paths shown in the model was found to be statistically significant. The Bentler-Bonettnormed fit index 
(NFI), The Tucker-Lewis coefficient fit index (TLI) and other fit indices showed that the model was wellmatched (Table 1). Each of the two-way correlations between endogenous data in the model has high values and is statistically significant. This situation is also affected by the correlation values of the subdimensions of the values scale used in the study.

In our study, the following conclusions have been reached based on the findings about the predictive relationships between the values of adolescents, hopelessness and psychological resilience.

1. When we look at the findings of the study, it is observed that the most important independent variable that affects psychological strength is the values. The result reveals that the psychological strength of adolescents will vary according to their values. In other words, according to the findings obtained, it was seen that as the values of adolescents increased, psychological resilience levels increased.

2. According to the research results, it is seen that the most important independent variable affecting the hopelessness levels of adolescents is values. In other words, in line with the findings obtained, it is revealed that the levels of hopelessness will decrease with the increase in the values of adolescents

According to the results of the research, the following suggestions were made.

1. This study was carried out with adolescents in Konya. Repeating this study with young people in different places would be useful in terms of contributing to the generalization of our study to a wider universe.

2. The sample of the present study is limited to adolescents (9th, 10th, 11th, 12th grade) who continue their education in high school. In other words, it is not possible to generalize the research results to different age groups. In this respect, applying similar studies to different age categories will enable more detailed data to be obtained.

3. The relationships between the values of adolescents and their levels of hopelessness and psychological resilience are included. It is concluded that the values present in adolescents predict psychological resilience and hopelessness levels. In this respect, the effects of a structured values education program on adolescents' psychological resilience and hopelessness can be investigated.

4. Values, Turkey has not seen the resilience and hopelessness that are the subject of working together. Implementation of new research studies in which these concepts are dealt with together will contribute to a thorough understanding of the relationships between these variables. 